\title{
Prunus tomentosa as a Diagnostic Host for Detection of Plum Pox Virus and Other Prunus Viruses
}

\author{
V. D. Damsteegt, USDA-ARS, Ft. Detrick, Frederick, MD 21702; H. E. Waterworth, USDA-ARS, Glenn Dale, \\ MD 20769; G. I. Mink and W. E. Howell, Washington State University-Prosser, Prosser 99350; and L. Levy, \\ USDA-ARS, Beltsville, MD 20705
}

\begin{abstract}
Damsteegt, V. D., Waterworth, H. E., Mink, G. I., Howell, W. E., and Levy, L. 1997. Prunus tomentosa as a diagnostic host for detection of plum pox virus and other Prunus viruses. Plant Dis. 81:329-332.

The efficacy of seedlings of Prunus persica cv. GF 305, P. persica cv. Siberian C, and $P$. tomentosa (Nanking Cherry) as diagnostic indicators of plum pox infection, and of $P$. tomentosa for other Prunus viruses was evaluated by graft-inoculation with eight different strains or isolates of plum pox virus (PPV) representative of the Marcus (M) and Dideron (D) serogroups; and one isolate each of Prunus necrotic ringspot virus (PNRSV), prune dwarf virus (PDV), and sour cherry green ring mottle virus (GRMV). The initial PPV symptoms that developed in $P$. tomentosa within 30 days after inoculation were chlorotic banding along the midrib spreading to lateral veins from the leaf base upward, giving the appearance of a chlorotic oak-leaf pattern. Symptoms caused by PPV-M could be distinguished from those caused by PPV-D. Virus titers in infected P. tomentosa and GF 305 were higher than those in Siberian C when measured by triple antibody sandwich enzyme-linked immunosorbent assay. Infections by PNRSV, PDV, and GRMV were evident with the first flush of vegetative growth.
\end{abstract}

Additional keywords: virus indexing

Some viruses affecting Prunus species are detectable and identifiable primarily through the use of various virus-sensitive indicator plants. Plum pox virus (PPV) is routinely detected by grafting infected buds onto specific Prunus indicator plants, i.e., P. persica (L.) Batsch cvs. GF 305 or Siberian $\mathrm{C}$, or by mechanical transmission to Chenopodium foetidum Schrad., Nicotiana clevelandii Gray, or $N$. benthamiana Domin. $(4,8)$. While P. tomentosa (Thunb.) has been used as a diagnostic indicator for PPV and other viruses by some investigators $(5,10)$, it has not been used widely for this purpose. Although new immunological and molecular detection methods have been developed $(1,2,12)$, uneven distribu-

Corresponding author: V. D. Damsteegt

E-mail: damsteeg@nc.fcrf.gov

The names reported in this paper are necessary to report factually on available data. However, the USDA neither guarantees nor warrants the standard of the product, and the use of the name by USDA implies no approval of the product to the exclusion of others that may also be suitable.

Accepted for publication 16 January 1997.

Publication no. D-1997-0225-04R

This article is in the public domain and not copyrightable. It may be freely reprinted with customary crediting of the source. The American Phytopathological Society, 1997. tion and titer of viruses in different plant tissues, seasonal fluctuations in virus titer, lack of laboratory facilities and trained personnel, and inconsistent immunological results have sustained a high level of interest in the use of reliable biological tests with woody indicator plants (8).

There are two major serogroups of PPV $(1,2,12)$. The Marcus serotype (PPV-M) produces chlorotic spots, blotches and mosaic patterns on leaves, spots and rings on young fruit which become necrotic and sunken during ripening, fruit deformation and premature fruit drop in apricot, peach GF 305, and plums, and mosaic symptoms in $N$. benthamiana. The Dideron serotype (PPV-D) incites less severe chlorosis and necrosis in plum, symptoms comparable to PPV-M in apricot and peach GF 305, and delayed symptoms in $N$. benthamiana (M. Ravelonandro, personal communication). The serotypes cannot be differentiated on GF 305. A third symptomatic variant of PPV, which is serologically similar to PPVD, was reported from Egypt (9), and a fourth variant was recently reported from sour cherry (7). The sour cherry isolate produces very mild chlorotic patterns in $P$. tomentosa.

P. persica cv. GF 305 (8), mentioned above, is a widely used diagnostic indicator of PPV. The scarcity of GF 305 seeds has resulted in the use of $P$. persica $\mathrm{cv}$. Siberian $\mathrm{C}$ seedlings, on which symptoms of PPV are less obvious or absent. This study describes the general usefulness and serogroup specificity of $P$. tomentosa (Nanking Cherry) as a diagnostic indicator for PPV and three other viruses. A preliminary account of these results has been reported (3).

\section{MATERIALS AND METHODS}

Virus isolates. Isolates of PPV were obtained from Prunus germ plasm collections (Romania), from infected peach and plum budwood (M. Ravelonandro, Bordeaux, France), and from infected tobacco tissue (American Type Culture Collection [ATCC], Rockville, MD). The Romanian sources were identified as isolates $22903 \mathrm{~A}$, 24821, 24825B, 24829A2, and 24830A, which had been graft-transmitted to GF 305 or were in original budwood sources. The five isolates from Ravelonandro were PPV-Salon de Provence and PPV-D (France), PPV-Red Beaut (Spain), PPV-M (Greece), and PPV-El Amar (Egypt). The isolate from ATCC (PV-286) originated in Hungary and was maintained in $N$. benthamiana. The endemic virus isolates (Prunus necrotic ringspot virus [PNRSV], prune dwarf virus [PDV], and sour cherry green ring mottle virus [GRMV]) were obtained as infected budwood from the National Research Support Project No. 5 (NRSP5/IR2) located at Washington State University, Prosser. Each virus source had been screened previously and was considered free of other known viruses and grafttransmitted pathogens of Prunus.

Test plants. Dormant, bare-rooted seedlings of $P$. tomentosa (IR473 $\times$ IR474 hybrid) from NRSP5/IR2, and seedlings of GF 305 and Siberian C from the National Plant Germplasm Quarantine Center, Beltsville, MD, were transplanted into 15$\mathrm{cm}$ (6 in) clay pots in a 50:50 mix of MetroMix 510 (Grace Sierra Horticultural Products Co., Milpitas, CA) and a greenhouse soil mixture. The plants were maintained at 18 to $25^{\circ} \mathrm{C}$. Supplemental lighting with high-pressure sodium lamps extended day length to $16 \mathrm{~h}$, with intensities ranging from $32 \mu \mathrm{E} \cdot \mathrm{s}^{-1} \cdot \mathrm{m}^{-2}$ at bench level to 95 $\mu \mathrm{E} \cdot \mathrm{s}^{-1} \cdot \mathrm{m}^{-2}$ at plant tops. All plants were fertilized weekly with a dilute solution of Peters 20N-20P-20K (Grace Sierra Horticultural Products). 
Inoculations. Virus transmissions for each isolate were accomplished by grafting two bark chips (with or without a nodal bud) onto actively growing seedlings; grafted buds were allowed to grow out. Virus negative controls consisted of grafts with budwood from healthy GF 305 . Inoculated plants were maintained in Fre- derick, MD, under quarantine conditions in keeping with USDA Permit 902428.

Experimental procedures. Experiment

$I$. Five $P$. tomentosa seedlings were grafted
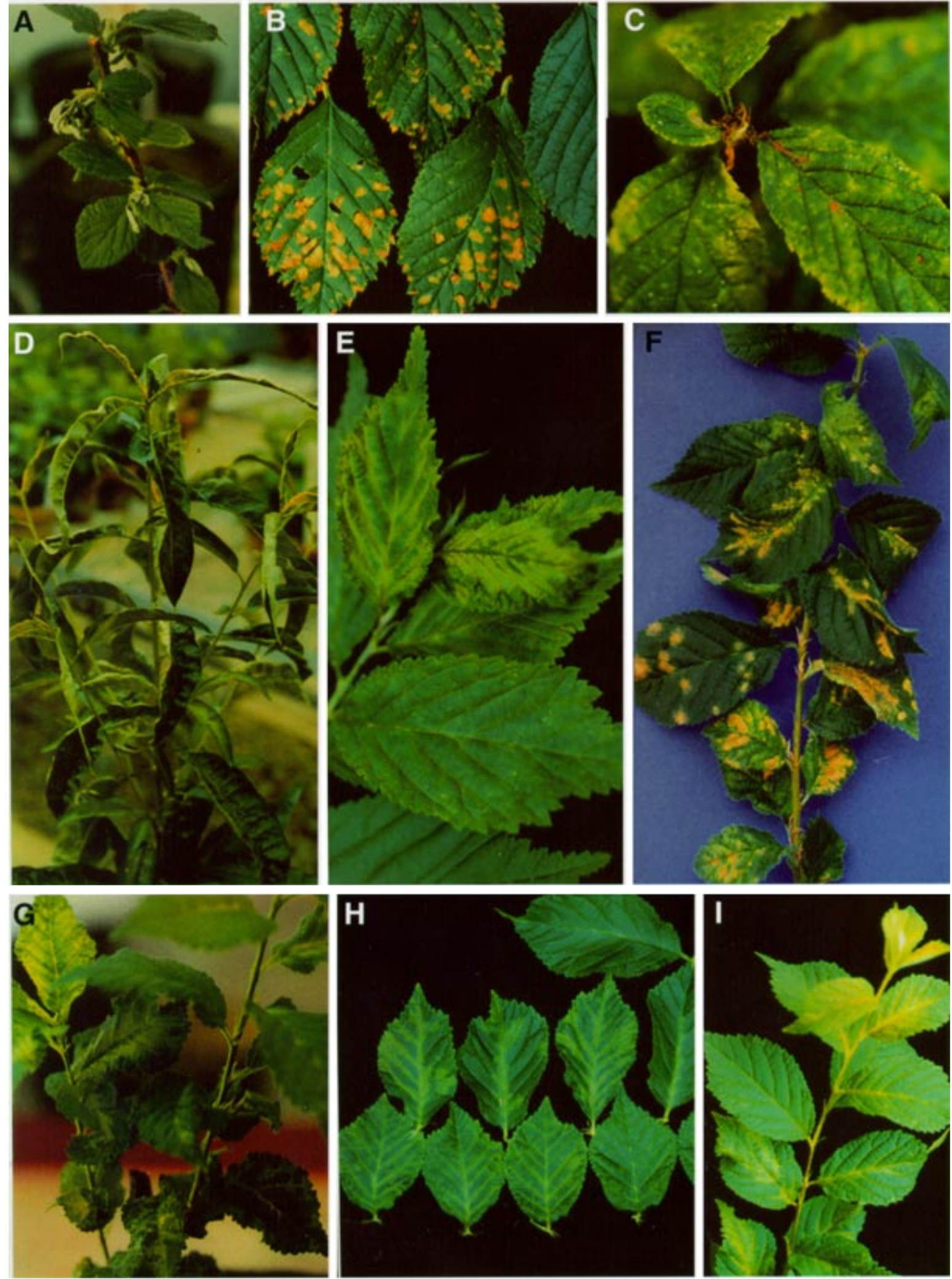

Fig 1. Prunus tomentosa graft-inoculated with endemic Prunus viruses (A to C) and exotic PPV (D to I) virus isolates: (A) Prunus necrotic ringspot showing necrotic shock reaction as buds emerge, later growth asymptomatic; (B) prune dwarf with shot hole symptoms; (C) cherry green ring mottle showing chlorotic leaf margins, necrosis, and leaf twisting; (D) peach cv. GF 305 infected with PPV-D from Romania showing chlorotic veins, leaf twisting, and irregular margins; (E, F) plum pox (Marcus serotype) from Greece showing strong chlorotic and necrotic patterns; (G, H) plum pox (Dideron serotype) showing chlorotic vein patterns; and (I) plum pox (El Amar type) showing chlorotic, vein-associated patterns with some necrotic flecking. 
with each Romanian PPV isolate, pruned to 3 to $4 \mathrm{~cm}$ above the top graft, and all side branches removed. Symptoms were recorded as they appeared in the new growth flush. Test plants were cut back and defoliated four additional times at 6- to 8week intervals and observed for symptom development.

Experiment II. PNRSV, PDV, and GRMV were graft-inoculated into five seedlings of $P$. tomentosa as in experiment I, and symptoms were recorded.

Experiment III. Romanian PPV isolates 22903A, 24825B, and 24830A and five isolates from France, Greece, Spain, and Egypt were grafted onto six replicate $P$. tomentosa per isolate and one seedling each of GF 305 and Siberian C. All plants were pruned to $5 \mathrm{~cm}$ above the inoculum bark chips after 21 days to induce new vegetative growth. Symptoms were recorded up to 70 days postinoculation, after which the plants were pruned to $30 \mathrm{~cm}$ and allowed to regrow. Leaves from vigorously growing plants were assayed using triple antibody sandwich enzyme-linked immunosorbent assay (TAS-ELISA) (6). Volumes were $150 \mu \mathrm{l}$ per well in paired wells in Maxisorp microplates (A/S Nunc, Kamstrup, Denmark). Polyclonal antiserum to PPV-W $(1: 1,000)$ (BIOREBA AG, Basil, Switzerland) was used as a capture antibody. An intermediate unlabeled potyvirus group-specific monoclonal antibody (1:100) (Agdia, Elkhart, IN) was added followed by alkaline phosphatase conjugated goat-antimouse antibody (1:500) (Kirkegaard \& Perry, Gaithersburg, MD). Results were visualized using $p$-nitrophenyl phosphate fast-tabs (Sigma Chemical Co., St. Louis, Mo.) and recorded using a Multiskan+ microplate reader (TiterTek, Labsystems, Finland) at $405 \mathrm{~nm}$.

\section{RESULTS}

Experiment I. Each of the Romanian isolates produced symptoms in two or more of the five $P$. tomentosa test plants.
Symptoms initially appeared as chlorotic banding along the midrib beginning at the base of the leaf and radiating out along the secondary veins, resulting in a chlorotic oak-leaf pattern. Symptoms sometimes occurred only in the lower, midbranch, or upper leaves, depending on the individual plant. Additional symptoms included chlorotic interveinal blotches culminating in an oak-leaf pattern, leaf distortion, and twisting. Chlorotic areas in new leaves often became necrotic as leaves aged. Diagnostic symptoms appeared on each new growth flush on four successive prunings. Only visual symptoms were recorded for this group of test plants.

Experiment II. Discrete symptoms occurred with PNRSV, PDV, and GRMV. Symptoms incited by PNRSV and PDV appeared with the first flush of leaves, approximately 20 days after grafting. New leaves displayed epinasty, reduced leaf area, and necrosis (Fig. 1A). Following a necrotic shock reaction, the PNRSV- and PDV-infected plants produced asymptomatic leaves and shoots. Mature leaves of PDV-infected plants, however, developed chlorotic to necrotic lesions and shot hole symptoms (Fig. 1B). Symptoms were expressed in GRMV-infected plants within the first growth flush (20 days after grafting) and consisted of distinct, yellow coloration along leaf margins, leaf curling and deformation, and reduced growth (Fig. 1C). GRMV-infected plants were stunted, and symptoms were persistent in the new growth.

Experiment III. Comparisons were made between PPV symptoms in $P$. tomentosa and the standard woody indicators GF 305 and Siberian C. Symptoms of plum pox infection became evident in $P$. tomentosa with the first flushes of leaves produced, 20 to 30 days postgrafting. In some cases, these symptoms were apparent prior to the first pruning, but generally leaves produced following the first pruning were most symptomatic.
Symptoms in GF 305 consisted of chlorosis associated with tissue located along primary and secondary veins, twisted leaves, and reduced growth (Fig. 1D). Symptoms in Siberian C consisted of mild chlorotic banding along the veins and some leaf distortion. Despite healed grafts, most Siberian C plants were asymptomatic.

Four of the eight PPV isolates tested in experiment III (PPV-M, PPV-Salon de Provence, 22903A, and 24830A) were of the PPV-M serogroup. All produced strong chlorotic, vein-associated patterns in $P$. tomentosa quickly followed by necrotic flecking and vein-associated necrotic patterns (Fig. 1E and F). The three isolates of the PPV-D serogroup (PPV-Spain, PPV-DFrance, and 24825B produced only chlorotic, vein-associated patterns in $P$. tomentosa (Fig. 1G and $\mathrm{H}$ ); however, after several weeks, some of the chlorotic areas became necrotic. The El Amar isolate from Egypt produced mild chlorotic patterns with some necrotic flecking (Fig. 1I).

All plants with symptoms tested positive for PPV by ELISA (Table 1). Not all $P$. tomentosa plants became infected, although all grafts appeared healed.

\section{DISCUSSION}

Plum pox virus is very destructive to crop production wherever it occurs. PPV does not occur in North America, and because of the concern for exclusion of PPV from Prunus germ plasm, there is considerable interest in having a diversity of detection methods available. Among these methods are sensitive woody test plants.

Although peach GF 305 is an effective and widely used indictor to detect Prunus viruses $(4,11)$, it has the disadvantages of being sensitive to sudden collapse in the greenhouse by overwatering; and in many years, we have experienced a limited seed supply. On the other hand, P. tomentosa is easily grown, grows rapidly, and can be repeatedly pruned to stimulate new growth for expression of virus symptoms. It has

Table 1. Results of triple antibody sandwich enzyme-linked immunosorbent assay (TAS-ELISA) ${ }^{\mathrm{a}}$ of Prunus tomentosa graft-inoculated with several isolates of plum pox virus (PPV) in experiment III

\begin{tabular}{|c|c|c|c|c|c|c|}
\hline \multirow[b]{2}{*}{ Virus isolates } & \multicolumn{6}{|c|}{ Absorbance values (405 nm) } \\
\hline & Plant $\mathbf{1}^{\mathrm{b}}$ & Plant 2 & Plant 3 & Plant 4 & Plant 5 & Plant 6 \\
\hline PPV (Spain) & $2.60^{c}$ & $0.00^{\mathrm{d}}$ & 0.425 & 1.028 & & \\
\hline PPV (Salon de Provence) & 0.00 & 2.342 & 0.00 & 2.279 & 1.132 & 0.565 \\
\hline PPV-M (Greece) & 2.222 & 0.00 & 0.00 & 0.00 & 1.994 & 2.539 \\
\hline PPV-D (France) & 1.174 & 0.00 & 2.443 & 0.00 & 0.874 & \\
\hline PPV (22903A Romania) & 1.687 & 0.00 & 2.445 & 1.133 & 0.00 & \\
\hline PPV (24830A Romania) & 0.00 & 1.307 & 1.246 & 0.391 & 0.00 & 2.201 \\
\hline PPV (24825B Romania) & 0.206 & 0.501 & 2.000 & 0.028 & 0.00 & \\
\hline PPV (El Amar, Egypt) & 0.00 & 0.00 & 1.704 & 0.553 & 0.927 & 1.962 \\
\hline PPV (PV 286 Hungary) & $2.400^{\mathrm{e}}$ & & & & & \\
\hline PPV-D (GF 305 CK) & 2.500 & & & & & \\
\hline Healthy GF 305 & 0.00 & 0.00 & 0.00 & & & \\
\hline Healthy $P$. tomentosa & 0.00 & 0.00 & 0.00 & & & \\
\hline
\end{tabular}


been used in Serbia for 15 years (10) and is especially suited for tests conducted in the greenhouse $(5,8)$.

We agree with Rankovic (10) that $P$. tomentosa is an excellent woody indicator for PPV. Unlike Rankovic (10), we have shown the effectiveness of $P$. tomentosa to distinguish $\mathrm{D}$ versus $\mathrm{M}$ strains by symptoms, and we have shown that both strains produce high virus titers in infected plants (Table 1). Our P. tomentosa source was a hybrid line produced at the WSU-Prosser Experiment Station, which distinguished PPV-induced symptoms from those incited by PNRSV, PDV, and GRMV. It detected all the sources of PPV from Eastern Europe, Western Europe, and North Africa that were inoculated into it. It was better that peach GF 305 or Siberian $\mathrm{C}$ in differentiating between PPV-D and -M. Although all sources of PPV incited similar chlorotic symptoms initially, only those plants infected with PPV-M quickly developed extensive necrosis. In direct comparisons with GF 305 and Siberian $\mathrm{C}$, the symptoms on $P$. tomentosa were more distinctive for both PPV serotypes.

Not all inoculated $P$. tomentosa plants became infected, which is a result of the uneven distribution of PPV in Prunus. When used in an indexing program, based on the results shown in Table 1 , we recommend the use of at least five replicate $P$. tomentosa plants.

\section{LITERATURE CITED}

1. Asensio, M., Gorris, M. T., Sanz, A., Carbonell, E., and Cambra, M. 1994. Characterization and detection of plum pox virus using monoclonal antibodies. Acta Hortic. 386:354-356.

2. Candresse, T., MacQuaire, G., Lanneau, M., Bousalem, M., Quiot-Douine, L., Quiot, J. B., and Dunez, J. 1995. Analysis of plum pox virus variability and development of strain-specific PCR assays. Acta Hortic. 386:357-369.

3. Damsteegt, V. D., Waterworth, H. E., Mink, G. I., Howell, W. E., and Levy, L. 1994. Prunus tomentosa, bioindicator for plum pox virus. (Abstr.) Phytopathology 84:1152.

4. Desvignes, J. C. 1976. The virus diseases detected in greenhouse and in field by the peach seedling GF 305 indicator. Acta Hortic. 67:315-323.
5. Fridlund, P. R. 1961. Temperature effects on virus disease symptoms in some Prunus, Malus, and Pyrus cultivars. Wash. Agric. Exp. Stn. Bull. 726.

6. Jordan, R., and Hammond, J. 1991. Comparison and differentiation of potyvirus isolates and identification of strain-, virus-, subgroupspecific and potyvirus group-common epitopes using monoclonal antibodies. J. Gen Virol. 72:25-36.

7. Nemchinov, L., and Hadidi, A. 1996. Characterization of the sour cherry strain of plum pox virus. Phytopathology 86:575-580.

8. Nemeth, M. 1986. Virus, Mycoplasma, and Rickettsia Diseases of Fruit Trees. Martinus Nijhoff, Dordrecht, The Netherlands.

9. Pasquini, G., Mazzei, M., Pilotti, M., and Barba, M. 1995. Characterization of PPV isolates using monoclonal antibodies. Acta Hortic. 386:346-353.

10. Rankovic, M. 1980. Use of Prunus tomentosa for the detection and differentiation of sharka and other viruses of plum. Acta Phytopathol. 15:303-308.

11. Waterworth, H. E. 1994. Viruses detected in stone fruit germplasm entering the United States. HortScience 29:917.

12. Wetzel, T., Candresse, T., Ravelonandro, M., and Dunez, J. 1991. A polymerase chain reaction adapted to plum pox potyvirus detection. J. Virol. Methods 33:355-366. 